Research Article

\title{
Elaboration and Biocompatibility of an Eggshell-Derived Hydroxyapatite Material Modified with Si/PLGA for Bone Regeneration in Dentistry
}

\author{
Sandra Janeth Gutiérrez-Prieto $(\mathbb{D}),{ }^{1}$ Luis F. Fonseca, ${ }^{2}$ Luis Gonzalo Sequeda-Castañeda $(\mathbb{D}),{ }^{3}$ \\ Kelly J. Díaz, ${ }^{4}$ Linet Y. Castañeda, ${ }^{4}$ José A. Leyva-Rojas, ${ }^{5}$ Juan Carlos Salcedo-Reyes $\mathbb{D},{ }^{5}$ \\ and Adriana P. Acosta ${ }^{6}$ \\ ${ }^{1}$ Department of Dental Systems, Dentistry Research Centre, School of Dentistry, Pontificia Universidad Javeriana, \\ Bogotá 110231, Colombia \\ ${ }^{2}$ Resident in Pathology and Oral Surgery, School of Dentistry, Pontificia Universidad Javeriana, Bogotá 110231, Colombia \\ ${ }^{3}$ Department of Chemistry, Faculty of Sciences, Pontificia Universidad Javeriana, Bogotá 110231, Colombia \\ ${ }^{4}$ Faculty of Sciences and Education, Universidad Distrital Francisco José de Caldas, Bogotá 110231, Colombia \\ ${ }^{5}$ Department of Physics, Faculty of Sciences, Pontificia Universidad Javeriana, Bogotá 110231, Colombia \\ ${ }^{6}$ Department of Periodontal Systems, Dentistry Research Centre, School of Dentistry, Pontificia Universidad Javeriana, \\ Bogotá 110231, Colombia
}

Correspondence should be addressed to Sandra Janeth Gutiérrez-Prieto; s.gutierrez@javeriana.edu.co

Received 12 July 2019; Revised 7 October 2019; Accepted 4 November 2019; Published 5 December 2019

Academic Editor: Saso Ivanovski

Copyright (c) 2019 Sandra Janeth Gutiérrez-Prieto et al. This is an open access article distributed under the Creative Commons Attribution License, which permits unrestricted use, distribution, and reproduction in any medium, provided the original work is properly cited.

\begin{abstract}
Hydroxyapatite (HAp) is the most commonly used biomaterial in modern bone regeneration studies because of its chemical similarity to bone, biocompatibility with different polymers, osteoconductivity, low cost, and lack of immune response. However, to overcome the disadvantages of HAp, which include fragility and low mechanical strength, current studies typically focus on property modification through the addition of other materials. Objective. To develop and evaluate the biocompatibility of a HAp material extracted from eggshells and modified with silicon ( $\mathrm{Si}$ ) and poly(lactic-co-glycolic) acid (PLGA). Materials and Methods. An in vitro experimental study in which a HAp material prepared from eggshells was synthesized by wet chemical and conventional chemical precipitation. Subsequently, this material was reinforced with Si/PLGA using the freezing/lyophilization method, and then osteoblast cells were seeded on the experimental material (HAp/Si/PLGA). To analyse the biocompatibility of this composite material, scanning electron microscopy (SEM) and fluorescence confocal microscopy (FCM) techniques were used. PLGA, bovine bone/PLGA (BB/PLGA), and HAp/PLGA were used as controls. Results. A cellular viability of $96 \%$ was observed for the experimental HAp/Si/PLGA material as well as for the PLGA. The viability for the BB/PLGA material was $90 \%$, and the viability for the HAp/PLGA was $86 \%$. Cell adhesion was observed on the exterior surface of all materials. However, a continuous monolayer and the presence of filopodia were observed over both external and internal surface of the experimental materials. Conclusions. The HAp/Si/PLGA material is highly biocompatible with osteoblastic cells and can be considered promising for the construction of three-dimensional scaffolds for bone regeneration in dentistry.
\end{abstract}

\section{Introduction}

Every day, a significant number of people are affected by multiple procedures in the oral cavity, such as traumas, surgical resections, congenital defects, pathologies, and frequent chronic infections, including caries and periodontal disease that can lead to bone loss $[1,2]$. Accordingly, the need for bone fillings and implants has increased in dental and medical clinical procedures, with bone grafting now one of the most frequently completed procedures each year [3]. 
Although the autograft is presented as the "gold standard" of clinical methods, due to its properties of biocompatibility, osteogenesis, osteoinduction, and osteoconduction, the autograft also possesses disadvantages such as morbidity of the donor site, the need for extensive surgeries, a high rate of reabsorption, and, above all, the limited availability of donor tissue, which has led some patients to forego treatment because of the scarcity of this tissue $[3,4]$. To overcome these disadvantages, strategies have been developed in the field of regenerative medicine, including substitution with alloplastic materials, which although lacking osteogenic properties, have good mechanical properties in the presence of small defects, lower resorption rates, and a single surgical intervention, thus offering significant potential for clinical applicability [5-7].

One of the most commonly used materials is hydroxyapatite (HAp), which is extracted from various sources [8-13]. One potentially reliable and alternative source is eggshells, which are composed mainly of calcium and have shown good results in the regeneration of bone tissue [14-18]. HAp, due to its chemical similarity to bone, exhibits biocompatibility, bioactivity, and osteoconductive capacity, which allows its integration into bone tissue, in addition to being low cost $[13,14,19-21]$. However, HAp also presents low mechanical strength, minimal flexibility, and an unpredictable osseointegration. This is why other materials have been proposed in order to improve these disadvantages [22-30].

Numerous studies show silicon ( $\mathrm{Si}$ ) as an element that contributes to the formation of the bone and extracellular matrix, which in turn activates collagen production, a fundamental component of the bone matrix that when incorporated into the HAp, it resembles the mineral phase present in the bone and provides properties such as osteoconductivity, porosity, and bioactivity leading to improved osseointegration [30-33].

Likewise, other studies have shown that the ( $\mathrm{Si}$ ) added in different percentages on the structure of the HAp improves the adhesion, growth, and proliferation of osteoblast cells on its surface and also favours the formation of bone in the early stages, thanks to this element it increases the solubility of HAp by reducing the size of its grain. However, some studies also show that the solubility caused by $\mathrm{Si}$ on HAp alters its structure and mechanical properties, which must be optimized, in order to obtain a material that can be used as scaffolding in the engineering of tissues [34-41].

A good option with which a structured compound could be obtained is polylactic-glycolic acid (PLGA). This polymer has mechanical properties very similar to the bone such as flexibility, mechanical strength, versatility in its architecture, and biodegradability; the last one is a very important property in this material since it can affect cell viability, so it has been managed considering its proportions. Recent studies show that it also can be use as biodegradable microspheres for compound release. Another characteristic of this material is its hydrophobicity, which is why it has been mixed and modified with other compounds that allow the formation of collagen and makes it more hydrophilic and therefore more biocompatible [42-50].

In this study, a compound of HAp/Si/PLGA was manufactured and its biocompatibility was evaluated in order to be used as a possible scaffold with applicability in bone regeneration in dentistry. The HAp obtained from the eggshell was doped with $\mathrm{Si}$ and structurally characterized by scanning electron microscopy and energy-dispersive X-ray spectroscopy (SEM-EDS) and Fourier-transform infrared spectroscopy (FTIR) and analysed by Raman spectroscopy. Subsequently, to this material, PLGA was added through the freezing-lyophilization method and osteoblast cells were seeded, and their biocompatibility was evaluated in vitro through fluorescence confocal microscopy (FCM) and SEM.

\section{Materials and Methods}

2.1. Elaboration of the HAp Material from Eggshells. HAp material was synthesized from eggshells using chemical precipitation [51, 52]. After cleaning the eggshells, a highefficiency mill was used to grind the eggshells and free them of impurities. Once the eggshell powder was obtained, a twostage oven heat treatment was applied. In the first stage, the eggshell powders were heated at $450^{\circ} \mathrm{C}$ for $2 \mathrm{~h}$ with a heating rate of $5^{\circ} \mathrm{C} / \mathrm{min}$, eliminating the organic compounds and leaving only calcium carbonate [51-53]. In the second stage, the calcium carbonate was heated at $900^{\circ} \mathrm{C}$ for $2 \mathrm{~h}$ at a heating rate of $0.5^{\circ} \mathrm{C} / \mathrm{min}$, which released carbon dioxide $\left(\mathrm{CO}_{2}\right)$ and yielded calcium oxide as the final product, as shown by the following reaction [51-53]:

$$
\text { Eggshell } \stackrel{\Delta}{\longrightarrow} \mathrm{CaCO}_{3} \stackrel{\Delta}{\longrightarrow} \mathrm{CaO}+\mathrm{CO}_{2}
$$

As a highly hygroscopic compound, calcium oxide is readily hydrated by ambient moisture, resulting in calcium hydroxide $\left(\mathrm{Ca}(\mathrm{OH})_{2}\right)$, as shown in the following reaction [53]:

$$
\mathrm{CaO}+\mathrm{H}_{2} \mathrm{O} \stackrel{\Delta}{\longrightarrow} \mathrm{Ca}(\mathrm{OH})_{2}
$$

To obtain a hydroxyapatite suspension, a suspension of calcium hydroxide $\mathrm{Ca}(\mathrm{OH})_{2}$ and a solution of $\mathrm{KH}_{2} \mathrm{PO}_{4}$ was prepared. The former suspension was added to the latter, dropwise, under conditions of mild heating and constant agitation. During this addition, the $\mathrm{pH}$ was maintained in a range of $10-11$ by employing a solution of ammonia $\left(\mathrm{NH}_{4} \mathrm{OH}\right)$ to obtain a stoichiometric hydroxyapatite $(\mathrm{Ca} / \mathrm{P})=1.67[54,55]$.

After complete addition, the reaction mixture was allowed to mature for $48 \mathrm{~h}$ at room temperature to remove any impurities. The precipitate was separated from the suspension by vacuum filtration and was then washed with distilled water until a $\mathrm{pH}$ of 8 was obtained. Subsequently, the filtered precipitate was oven-dried at $130^{\circ} \mathrm{C}$ for $6 \mathrm{~h}$ and was then pulverized with a mortar until a fine powder was obtained [54, 56].

$$
\begin{aligned}
10 \mathrm{Ca}(\mathrm{OH})_{2}+6 \mathrm{KH}_{2} \mathrm{PO}_{4} \longrightarrow & \mathrm{Ca}_{10}\left(\mathrm{PO}_{4}\right)_{6}(\mathrm{OH})_{2} \\
& +6 \mathrm{KOH}+12 \mathrm{H}_{2} \mathrm{O}
\end{aligned}
$$


2.2. Doping Hydroxyapatite with Silicon ( $\mathrm{KH}_{2} \mathrm{PO}_{4}$-TEOS). The hydroxyapatite extracted from the eggshells was doped with silicon, for which, by means of an acid-base neutralization reaction, the appropriate quantities of the precursors were mixed as follows: $0.500 \mathrm{~mol}$ of $\mathrm{Ca}(\mathrm{OH})_{2}$ obtained from the eggshells, $0.0289 \mathrm{~mol}$ of dipotassium phosphate $\left(\mathrm{KH}_{2} \mathrm{PO}_{4}\right)$, and $0.008 \mathrm{~mol}$ of tetraethyl orthosilicate (TEOS) (Sigma-Aldrich ${ }^{\circledR}$ ), which was the source of the silicon.

The precipitation reaction was carried out with constant heating and stirring, and the $\mathrm{pH}$ was maintained between 10 and 11 by the addition of ammonium hydroxide solution. After complete mixing of the precursors, the suspension was allowed to mature for $48 \mathrm{~h}$ and the resulting product was washed with distilled water, filtered, dried at $80^{\circ} \mathrm{C}$ for $6 \mathrm{~h}$, and subsequently ground and sieved (Figure 1) [56-58].

\subsection{Characterization of Hydroxyapatite Reinforced with Sil-} icon $(\mathrm{HAp} / \mathrm{Si})$. The HAp/Si material was characterized first by scanning electron microscopy and energy-dispersive X-ray spectroscopy (SEM-EDS) with a JSM-6490 LV of manufacture's house JEOL. Fourier-transform infrared spectroscopy (FTIR) was subsequently performed using Shimadzu Prestige-21. Finally, the material was analysed by Raman spectroscopy using an ID Raman Ocean Optics class 3B microscope $[57,58]$.

2.4. Addition of PLGA through the Freezing-Lyophilization Method. To add the PLGA to the material obtained from $\mathrm{HAp} / \mathrm{Si}, 0.73 \mathrm{~g}$ of PLGA (Sigma-Aldrich ${ }^{\circledR}$ ) and $8 \mathrm{ml}$ of chloroform at $0.1 \%$ were mixed with $2.19 \mathrm{~g}$ of the $\mathrm{HAp} / \mathrm{Si}$ powder in a ratio of $1: 3$, which was identified by considering the chemical composition of the bone. Once mixed in a $10 \mathrm{ml}$ centrifuge tube (Falcon), the mixture was maintained for $24 \mathrm{~h}$ in a shaker to ensure complete dissolution of the polymer. Subsequently, the mixture was transferred to a beaker and mixed with a magnetic stirrer for $4 \mathrm{~h}$, during which time $2 \mathrm{ml}$ of distilled water was added dropwise. The obtained mixture was transferred to plastic moulds (Cryovial) and frozen for $24 \mathrm{~h}$ at $-80^{\circ} \mathrm{C}$. After this process, the material was compacted every $4 \mathrm{~h}$ for 2 days and subsequently lyophilized at $-53^{\circ} \mathrm{C}$ for $24 \mathrm{~h}$ [59]. The samples were cut into disks with approximate dimensions of $6 \mathrm{~mm}$ (diameter) $\times 1.5 \mathrm{~mm}$ (thickness) and then sterilized with ethylene oxide [60].

2.5. Osteoblast Culture. Osteoblasts were acquired in vials of 500,000 cells from the third pass (3P) of human osteoblast cell line (from the Swiss company Lonza referenced as Clonetics $^{\text {TM }}$ Human Osteoblast Cell Systems). Each vial was thawed and then seeded in 2 culture flasks (S25), each containing 250,000 cells according to the protocol of the manufacturer. The culture medium used for these cells was OBM Clonetics ${ }^{\mathrm{TM}}$ supplemented with $5 \%$ foetal bovine serum (FBS), $0.1 \%$ insulin, $0.1 \%$ basic osteoblast growth factor, and $0.1 \%$ gentamicin/amphotericin $\mathrm{B}$. Media changes were performed one day after seeding and every two days thereafter. The cell subculture was performed when, microscopically, a confluence between 70 and $80 \%$ was reached when using the Lonza Clonetics ${ }^{\mathrm{TM}}$ Human Osteoblast Cell Systems kit under a saline solution wash, trypsinization, and neutralization, followed by centrifugation at $2000 \mathrm{rpm}$ for $5 \mathrm{~min}$. The cells were subsequently resuspended in medium, seeded again in boxes of $25 \mathrm{cms}$, and allowed to expand until the fifth pass (5P).

2.6. Seeding of the Osteoblasts on the HAp/Si/PLGA Material. Hydroxyapatite disks made from eggshells mixed with silicon and PLGA (HAp/Si/PLGA) (experimental group) and the materials used as controls, which included PLGA, bovine bone/PLGA (BB/PLGA), and hydroxyapatite extracted from eggshells/PLGA (HAp/PLGA), were previously sterilized with ethylene oxide for $24 \mathrm{~h}$ and ultraviolet light for $1 \mathrm{~h}$. Next, the disks were placed in boxes (well-transfer disks $35 \mathrm{~mm}$ in diameter) in triplicate, and subsequently, $1.5 \times 10^{5}$ osteoblastic cells from the sixth pass (6P) were seeded on top of each material. At 8 days after seeding, the biocompatibility of each material was evaluated.

\subsection{In Vitro Evaluation of the Biocompatibility of the HAp/Si/ PLGA Material}

2.7.1. Analysis of Cell Viability. Cellular viability was assessed using fluorescence correlation spectroscopy (FCS) performed on Olympus FV1000 using a Live/Dead kit (Invitrogen, Carlsbad, CA USA) that uses calcein (excitation at $495 \mathrm{~nm}$ and emission at $515 \mathrm{~nm}$ ), which discriminates living cells by green staining, and ethidium bromide (excitation $496 \mathrm{~nm}$ with emission at $635 \mathrm{~nm}$ ), which discriminates dead cells by red staining. Five microliters of calcein and $20 \mu \mathrm{l}$ of ethidium homodimer were mixed in $10 \mathrm{ml}$ of phosphate-buffered saline (PBS), following the instructions of the manufacturer. The culture medium of the cells in each box was removed, and $150 \mu \mathrm{L}$ of this solution was added directly to the cells on the material, allowing for 30 minutes of incubation before subsequent observation under a microscope. The percentages of the living and dead cells were estimated using ImageJ, which automatically counted the green and red cells present on the material using the following formula:

$$
\text { Cell viability }=\frac{\text { live cells }}{(\text { live cells }+ \text { dead cells })} \times 100 \text {. }
$$

2.7.2. Analysis of Cell Viability. Each of the matrices with cells was fixed with $2.5 \%$ glutaraldehyde for $4 \mathrm{~h}$ and subsequently dehydrated in increasing concentrations of ethanol $(75 \%, 90 \%$, and $100 \%)$ at 5, 10, and 20 minutes postfixation. The samples were passed through a critical point dryer (BALTEC CPD 030) and later were sputtercoated with a gold layer measuring $15 \mathrm{~nm}$ in thickness (BALTEC SCD 050). Once coated, the samples were observed under a scanning electron microscope (JEOL JSM$6490 \mathrm{LV}$ ) at an accelerating voltage of $15 \mathrm{kV}$, which was 


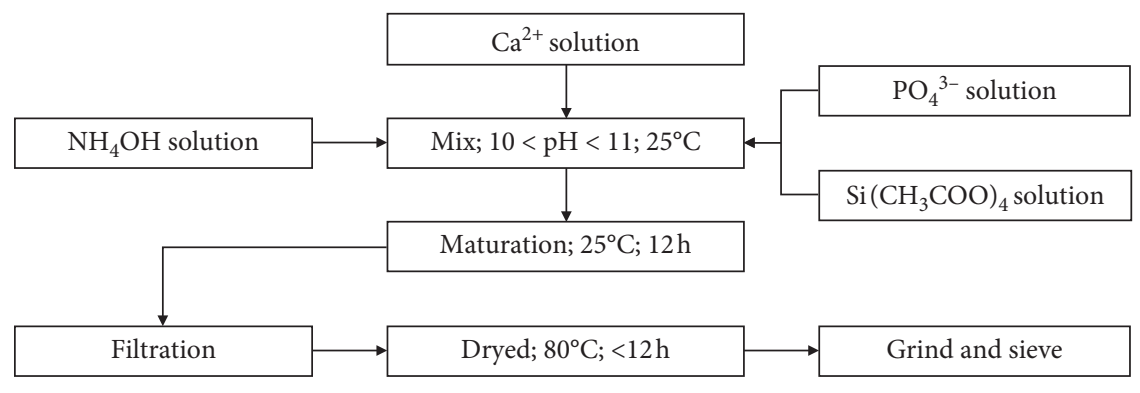

Figure 1: Flow diagram showing the synthesis of the HAp. The HAp material was prepared from the eggshell and synthesized by the conventional chemical precipitation method [54]. Afterwards, this was reinforced with Si/PLGA using the freezing/lyophilization method.

operated in the high-vacuum mode and equipped with a back-scattered electron detector.

\section{Results}

\subsection{Characterization of the HAp/Si/PLGA Obtained}

3.1.1. Fourier-Transform Infrared Spectroscopy (FTIR). Figure 2(a) shows the reference spectrum of the hydroxyapatite obtained from the bovine bone. In this spectrum, the bands identified at $3572 \mathrm{~cm}^{-1}$ and $632 \mathrm{~cm}^{-1}$ correspond to the stretching vibrations and structural flexion of hydroxyl groups $\left(\mathrm{OH}^{1-}\right)[16,19]$. The $1035 \mathrm{~cm}^{-1}$ band shows the stretching of the $\mathrm{P}-\mathrm{O}$ bond, while the bands at $1091 \mathrm{~cm}^{-1}$, $601 \mathrm{~cm}^{-1}$, and $570 \mathrm{~cm}^{-1}$ correspond to symmetric tension vibrations of the $\mathrm{P}-\mathrm{O}$ bond. These assignments are confirmed by the band at $962 \mathrm{~cm}^{-1}$, which is characteristic of the stretching of the phosphate group $\left(\mathrm{PO}_{4}{ }^{3-}\right)$ bonds $[16,17,22]$. The bands at $1458 \mathrm{~cm}^{-1}$ and $1421 \mathrm{~cm}^{-1}$ are characteristic of the flexion of the carbonate group $\left(\mathrm{CO}_{3}{ }^{2-}\right)$ impurities, which occur as a product of the exchange of phosphates $\left(\mathrm{PO}_{4}{ }^{3-}\right)$ by carbonates $\left(\mathrm{CO}_{3}{ }^{2-}\right)$; at $873 \mathrm{~cm}^{-1}$, a band corresponding to a vibration in the form of flexion due to impurities such as hydrogen phosphate $\left(\mathrm{HPO}_{4}{ }^{2-}\right)$ is observed [16, 17, 22].

Figure 2(b) shows the spectrum corresponding to the reaction between $\mathrm{Ca}(\mathrm{OH})_{2}$ and $\mathrm{KH}_{2} \mathrm{PO}_{4}$. The powders were sintered for further analysis. After sintering, bands are found at $3570 \mathrm{~cm}^{-1}$ and $634 \mathrm{~cm}^{-1}$, corresponding to stretching- and flexion-type vibrations of structural hydroxyl groups $\left(\mathrm{OH}^{1-}\right)$ $[13,16]$, as well as bands at $1047 \mathrm{~cm}^{-1}$ corresponding to the stretching of the $\mathrm{P}-\mathrm{O}$ bond, and at $1093 \mathrm{~cm}^{-1}, 603 \mathrm{~cm}^{-1}$, and $572 \mathrm{~cm}^{-1}$ corresponding to symmetric tension vibrations of the $\mathrm{P}-\mathrm{O}$ bond. These bands are consistent with the band that appears at $962 \mathrm{~cm}^{-1}$, which is characteristic of the stretching of the phosphate group $\left(\mathrm{PO}_{4}{ }^{3-}\right)$ bonds $[16,17,22]$.

Figure 2(c) shows the spectrum corresponding to $\mathrm{Ca}(\mathrm{OH})_{2}, \mathrm{KH}_{2} \mathrm{PO}_{4}$, and TEOS after the sintering process. In this spectrum, more defined bands are observed at $3572 \mathrm{~cm}^{-1}$ and $634 \mathrm{~cm}^{-1}$, both of which belong to the phosphate groups $\left(\mathrm{PO}_{4}{ }^{3-}\right)$. At $1047 \mathrm{~cm}^{-1}$, the PO bond stretching is observed; at $1091 \mathrm{~cm}^{-1}$ and $603 \mathrm{~cm}^{-1}$, structural stretching and bending vibrations of the hydroxyl groups $\left(\mathrm{OH}^{1-}\right)$ can be observed [16]. The band at $570 \mathrm{~cm}^{-1}$ corresponds to symmetric tension vibrations of the $\mathrm{P}-\mathrm{O}$ bond, which is confirmed by the presence of the phosphate group $\left(\mathrm{PO}_{4}{ }^{3-}\right)$ bond-stretching band at $962 \mathrm{~cm}^{-1}[16,17,22]$. Likewise, stretching, bending, and rolling bands of the Si-O bond are visible at $673 \mathrm{~cm}^{-1}$ [14], and finally, the band at $474 \mathrm{~cm}^{-1}$ can be assigned to the groups corresponding to the presence of silicon $\left(\mathrm{SiO}_{4}{ }^{-4}\right)$, which replace a fraction of the phosphate $\left(\mathrm{PO}_{4}{ }^{3-}\right)$ and hydroxyl $\left(\mathrm{OH}^{1-}\right)$ groups in the structure, the assignment of which is confirmed by the band appearing at $893 \mathrm{~cm}^{-1}$ [56].

3.1.2. Raman Spectroscopy. Figure 3(a) shows the reference spectrum of hydroxyapatite obtained from the bovine bone, where the bands observed at $1035 \mathrm{~cm}^{-1}, 1046 \mathrm{~cm}^{-1}$, and $1071 \mathrm{~cm}^{-1}$ correspond to the symmetric stretching of $\mathrm{P}-\mathrm{O}$ $[23,24]$, as confirmed by the assignment of the band at $956 \mathrm{~cm}^{-1}[22,28,29]$. The bands at $580 \mathrm{~cm}^{-1}, 589 \mathrm{~cm}^{-1}$, and $607 \mathrm{~cm}^{-1}$ are assigned to the O-P-O bond vibrations $[22,28,29]$. In addition, the folding bands of the O-P-O bond are assigned at $470 \mathrm{~cm}^{-1}$ and $428 \mathrm{~cm}^{-1}$ [29].

Figure 3(b) presents the spectrum that shows the reaction between $\mathrm{Ca}(\mathrm{OH})_{2}$ and $\mathrm{KH}_{2} \mathrm{PO}_{4}$ (HAp) due to sintering, as evidenced by the band at $1037 \mathrm{~cm}^{-1}$, which corresponds to the symmetric stretching of P-O $[23,24,26]$ and is confirmed by the assignment of the band at $953 \mathrm{~cm}^{-1}$ $[24,25,29]$. At $630 \mathrm{~cm}^{-1}$, the band corresponding to the release of hydroxide $\left(\mathrm{OH}^{1-}\right)$ is observed [23], which does not appear in the reference spectrum, and at $573 \mathrm{~cm}^{-1}$ and $409 \mathrm{~cm}^{-1}$, bands corresponding to the O-P-O bond vibrations are assigned [24, 28].

Figure 3(c) presents the spectrum corresponding to $\mathrm{Ca}(\mathrm{OH})_{2}, \mathrm{KH}_{2} \mathrm{PO}_{4}$, and TEOS (HAp/Si) after sintering. The bands at $1043 \mathrm{~cm}^{-1}$ and $1036 \mathrm{~cm}^{-1}$ show the symmetric stretching of P-O $[23,24,26]$, confirming the assignment of the band at $957 \mathrm{~cm}^{-1}[24,25,29]$. The band at $573 \mathrm{~cm}^{-1}$ is assigned as an O-P-O bond vibration $[24,28]$. In addition, the folding bands of the O-P-O bond [25] are assigned at $409 \mathrm{~cm}^{-1}$, and the band observed at $890 \mathrm{~cm}^{-1}$ is assigned to Si-O stretching [23].

3.2. Macrostructure of the HAp/Si/PLGA Material Obtained. Figure 4(a) (top) shows the macrostructure of the final Sidoped HAp material prepared by conventional chemical precipitation from eggshells and PLGA using freezing/lyophilization (HAp/Si/PLGA). The experimental material 


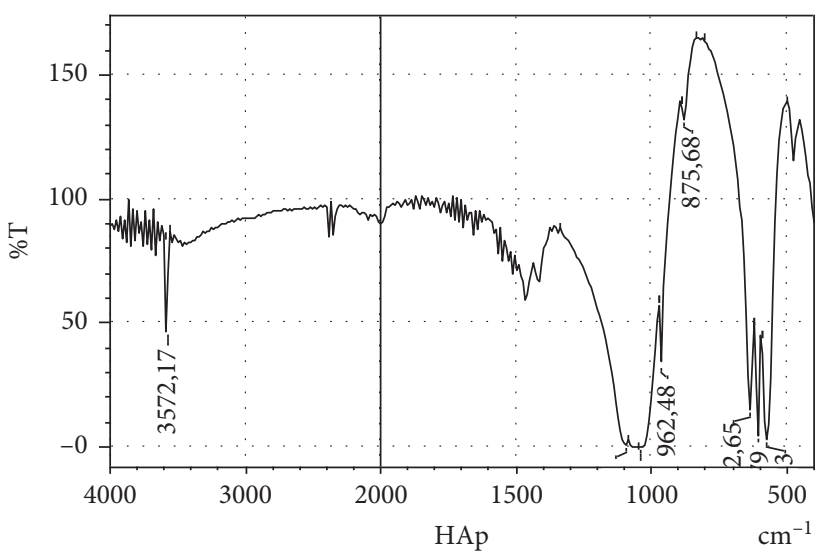

(a)

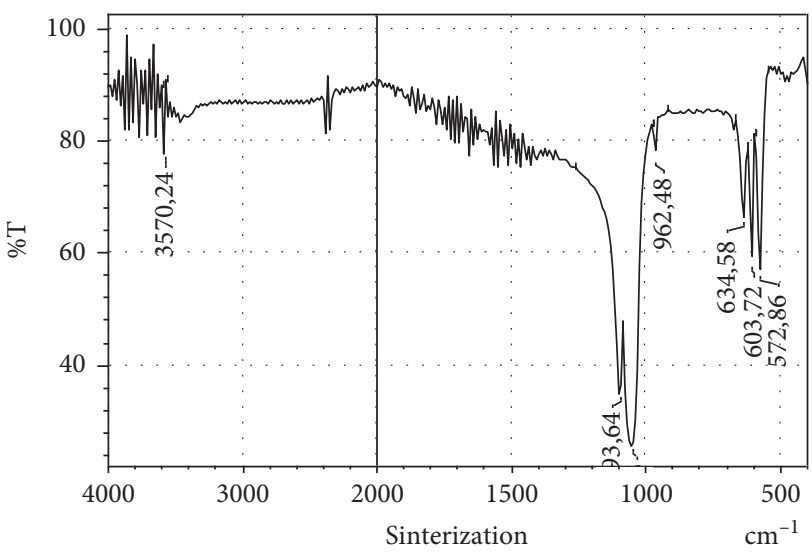

(b)

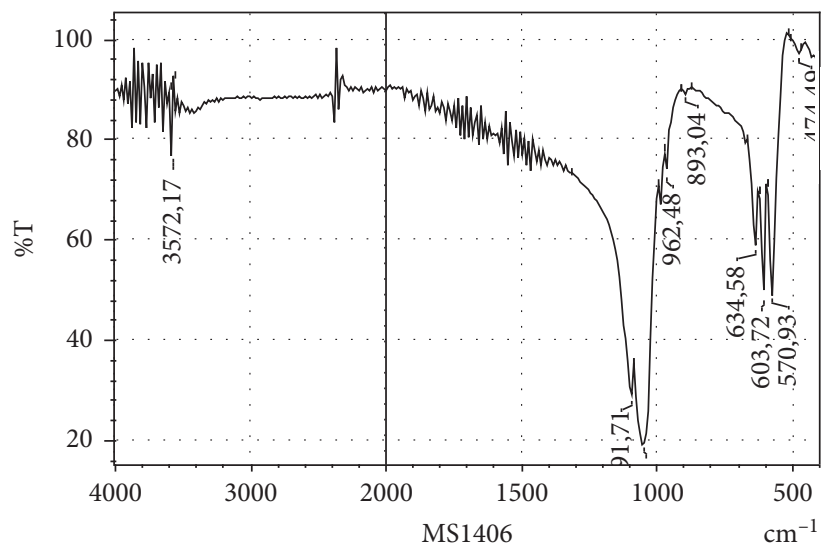

(c)

FIGURE 2: Spectra FTIR obtained from the hydroxyapatite material: bovine bone (a), eggshell (b), and eggshell doped with silicon (c).

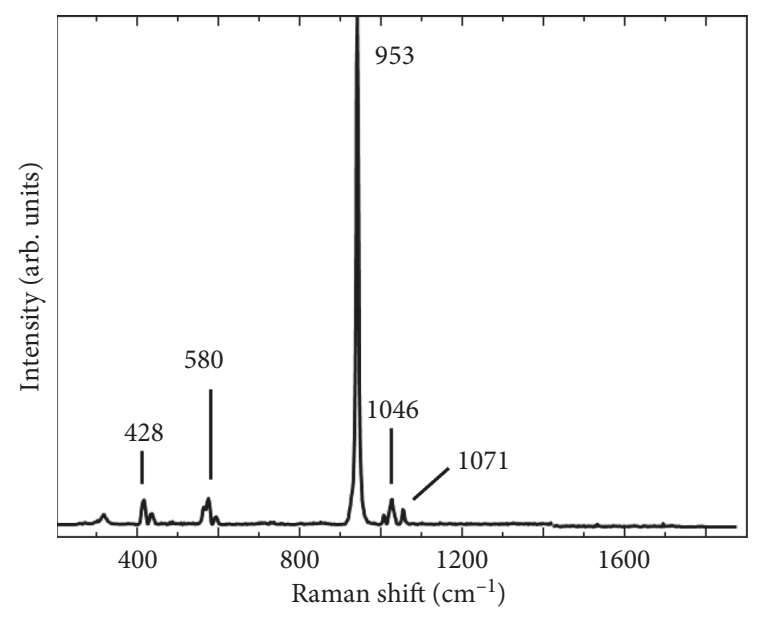

(a)

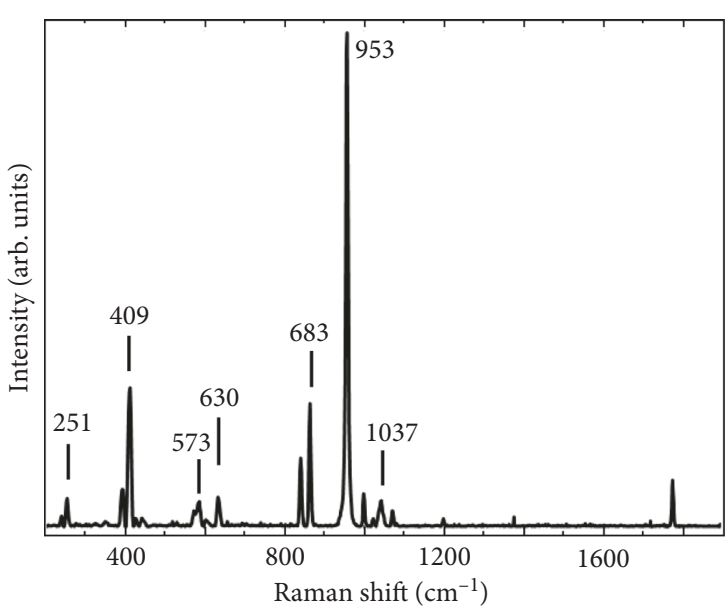

(b)

Figure 3: Continued. 


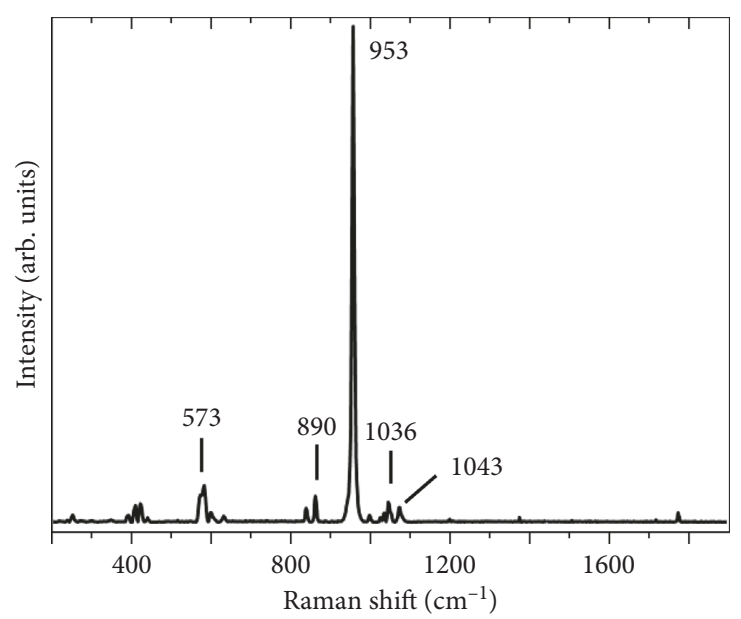

(c)

FIGURE 3: Spectra Raman obtained of hydroxyapatite material: bovine bone (a), eggshell (b), and eggshell doped with silicon (c).

obtained was white and irregular in shape. Subsequently, this material was cut into disks measuring approximately $6 \mathrm{~mm}$ (diameter) $\times 1.5 \mathrm{~mm}$ (thickness). In contrast, the PLGA disk used as one of the control materials was more compact and browner (Figure 4(a) low) The most fragile material was HAp + PLGA.

3.3. SEM-EDS Evaluation of the Structure of the HAp/Si/ PLGA Material. Figure 4(b) (top) shows the microstructure of the HAp/Si/PLGA material as observed using SEM at a magnification of 2500x. This image evidences an irregular, rough, and porous surface. In contrast, the PLGA control material exhibited a smoother surface, with several grooves and cracks (Figure 4(b) low). The EDS results confirmed the presence of silicon in the HAp/Si/PLG material at a concentration of $0.07 \%$.

\subsection{Evaluation of the Biocompatibility of the HAp/Si/PLGA Material Obtained}

3.4.1. Cell Viability by Fluorescence Correlation Spectroscopy (FCS). Figure 4(c) (top) shows the image obtained by confocal fluorescence spectroscopy using the Live/Dead kit on osteoblast cells at day 8 of culture on the experimental material and on the control (Figure 4(c) Low). The percentage of cell viability was evaluated for all materials using Image J software and is shown in the bar graph in Figure 4(e).

3.4.2. Evaluation of Cell Adhesion and Morphology by SEM. Figure 4(d) (top, middle, and low) shows the image obtained by SEM at day 8 of culture. A monolayer formation of osteoblast cells is observed on the external surface of all materials. The HAp/Si/PLGA material (Figure 4(d) top) shows on the external and internal surface filopodia characteristic of osteoblastic cells.

Furthermore, a HAp/Si control (Figure 5) was developed, as a point of comparison with the experimental material (HAp/Si/PLGA) in terms of its macro- and microstructure, and thus be able to observe the effect of Si on HAp without the addition of PLGA. In Figure 5(a), it is noted that the HAp/Si material presents great porosity, fragility, and a very whitish color. Microstructurally, it is observed that the grain size is small and oval and the architecture of the material is disordered and plain (Figure 5(b)). In contrast with the material to which the PLGA has been added (HAp/Si/PLGA), it is more compact, organized, less porous, and its color is slightly gray (Figure 4(a) top). Microscopically, it presents a larger grain size, less oval, more hexahedral, and organized with a moderated porosity (Figure 4(b) top). The HAp/Si material elaborated in this study upon contact with the culture medium for 8 days was dissolving until the material completely lost its initial architecture. However, cell viability can be seen through the FCM (Figure 5(c)), but SEM showed a lack in continuity of the monolayer due to the dissolution and fracture of the material (Figure 5(d)).

\section{Discussion}

To counteract the main disadvantages of HAp, such as its fragility and low mechanical strength, studies have focused on modifying its properties by forming HAp composites with different materials. Research shows that sintering of HAp at $1200^{\circ} \mathrm{C}$ increases its degree of crystallinity; however, when treated with $\mathrm{Si}$, a submicron and microporous grain is created, which has a higher biaxial flexural strength than pure HAp but lower crystallinity [28].

The HAp material studied in the present work was derived from chicken eggshells because their membranes contain widely used essential nutrients such as calcium carbonate $\left(\mathrm{CaCO}_{2}\right)$. Eggshells have typically been considered waste, with their usefulness in scientific applications underestimated. However, modern studies have focused on eggshells as a main component of HAp because they are extremely low cost, have unlimited availability, and are biocompatible and bioactive as a bone regeneration material [17]. 


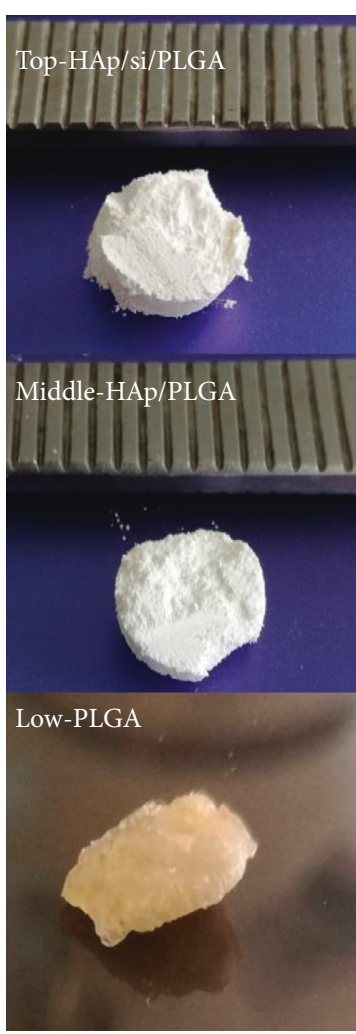

(a)

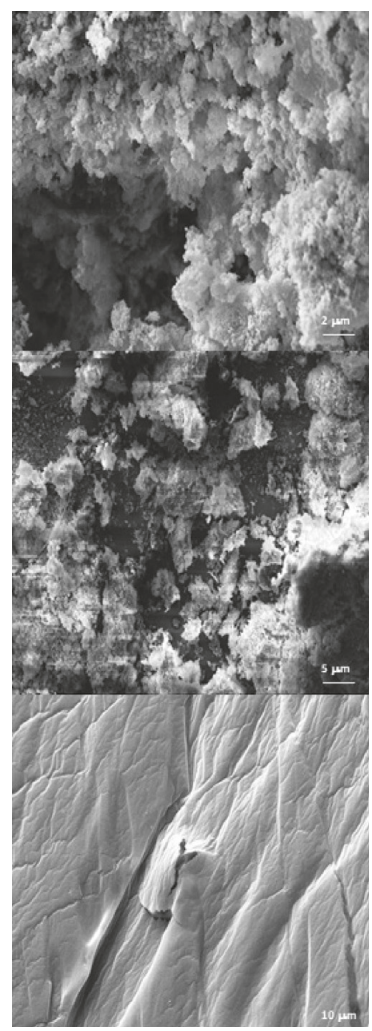

(b)

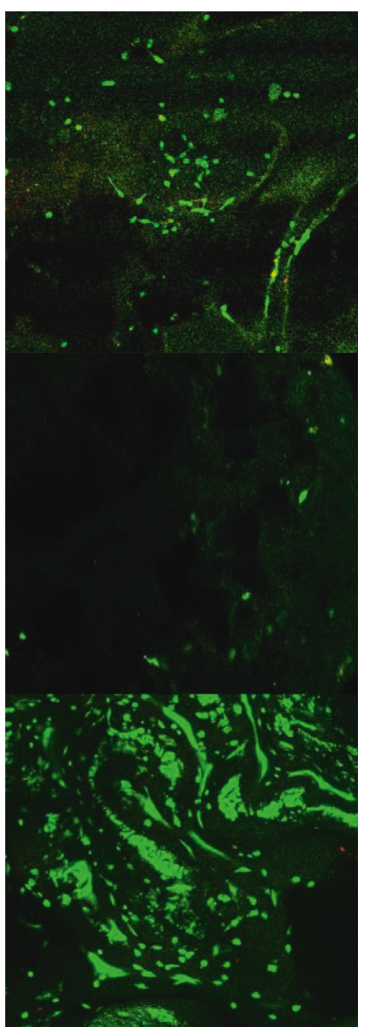

(c)

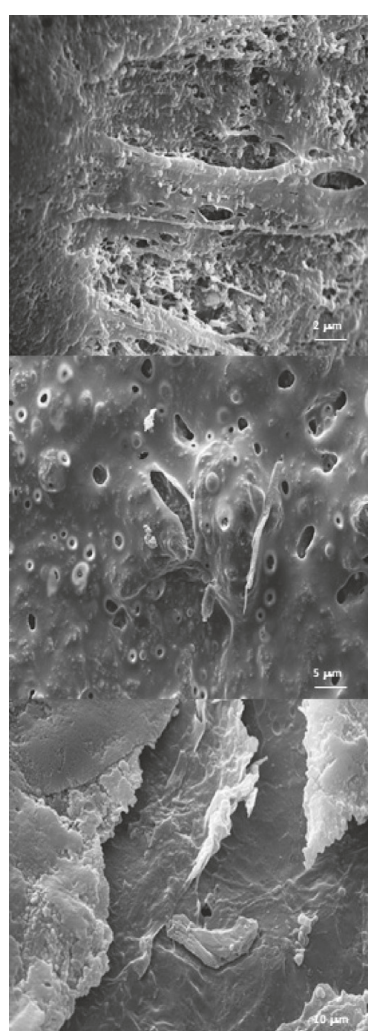

(d)

PLGA

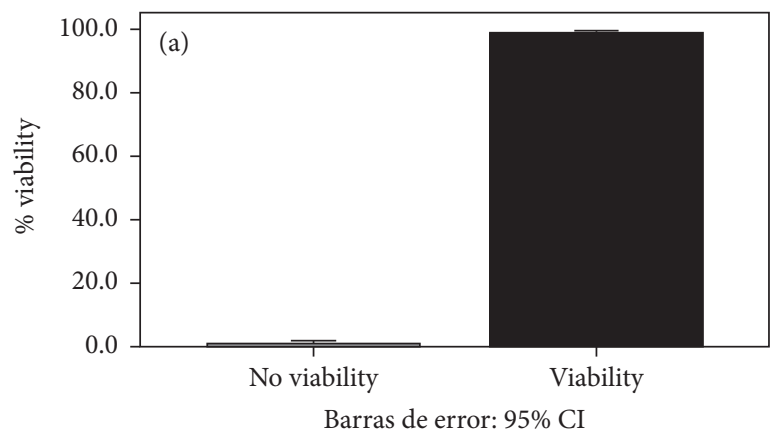

$\mathrm{HB}$

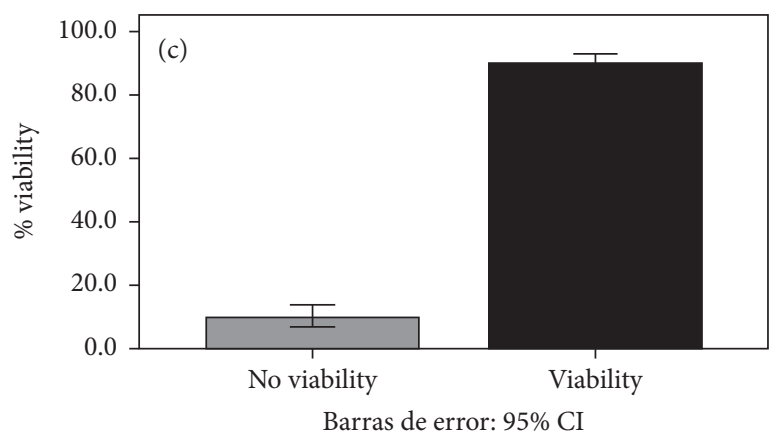

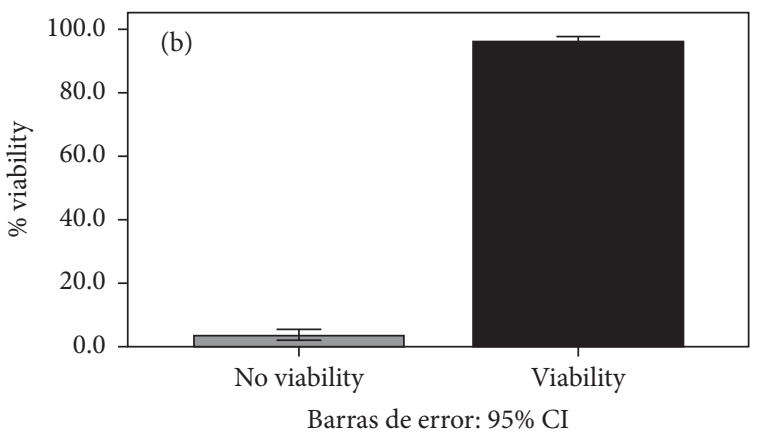

PSINT

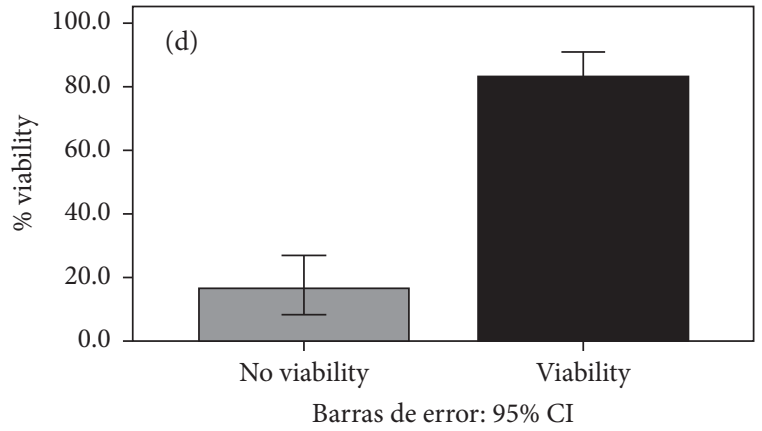

(e)

FIGURE 4: Structure and evaluation of the biocompatibility of the HAp/Si/PLGA material obtained, and its comparison with two of the control materials: HAp/PLGA and PLGA. Figure (e) Bar chart (ImageJ program) showing the viability percentage of the experimental material compared to the control materials. The highest percentage of live cells is observed in the PLGA (control, (a), and the HAp/Si/PLGA (b) (experimental) with a percentage of $96 \%$, and the lowest percentage was presented by the HAp/PLGA (d) (control) with a percentage of $86 \%$. The BB/PLGA shows a percentage of $90 \%$. 


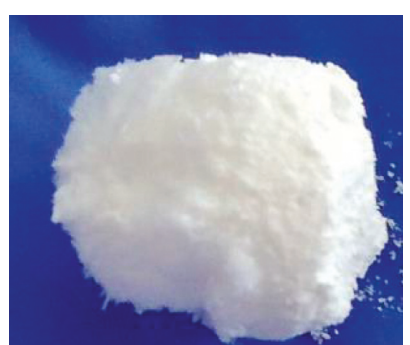

(a)

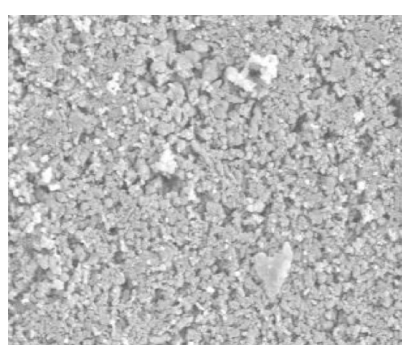

(b)

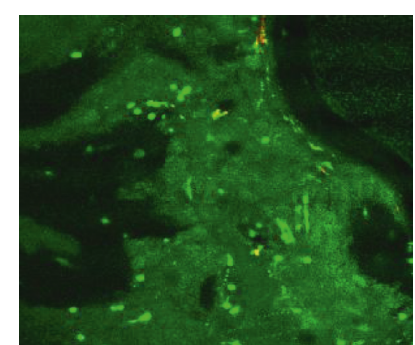

(c)

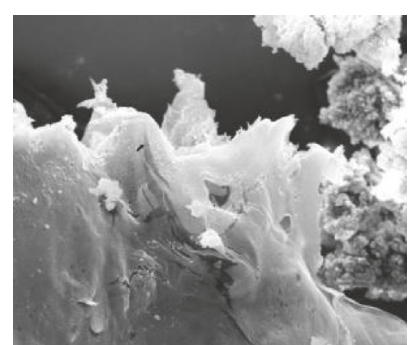

(d)

FIGURE 5: HAp/Si material: macrostructure (a) and microstructure (b) observed by SEM; cellular viability (c) observed by FCM and cellular adhesion and morphology (d) observed by SEM.

The eggshell-derived HAp material has shown enhanced bone formation in comparison to synthetic hydroxyapatite [17]. In addition, this material is cheaper than synthetic HAp material [41] and can be manufactured from different precursors, such as $\mathrm{K}_{2} \mathrm{HPO}_{4}$, yielding nearly uniform sizes and regular shapes [22].

This material was doped with $\mathrm{Si}$, and the methods used for analysis were SEM-EDS, FTIR spectroscopy, and Raman spectroscopy, which confirmed the presence of hydroxyapatite and substitution within the HAp structure by $\mathrm{Si}$ (Figures 2 and 3). It is known that the addition of Si to HAp improves the material's osteoconductivity and bioactivity due to the influence of Si on bone biochemistry, in addition to increasing the formation of new bone in vivo $[27,34]$ and the degree of mineralization [61].

The advantages associated with Si doping can be improved according to the proportions in which this material was added to the HAp in our study. Tsalsabila et al. [62] used the addition of $\mathrm{Si}$ proportions at $0.4 \%, 0.8 \%$, and $1.2 \%$ by weight to hydroxyapatite, resulting in the successful substitution within the hydroxyapatite of $\mathrm{Si}$ at proportions of $0.4 \%$ and, especially, $0.8 \%$. However, a decrease in the size of HAp crystals and a change in their shape were observed, showing more oval and less hexahedral crystals with no change in their surface [62].

In the present work, an average of $0.7 \% \mathrm{Si}$ substitution by weight led to a more porous structure (Figure $4(\mathrm{e})$ ) than that found with a fraction of $0.8 \%$. At this amount, Si reduces the crystallinity of the structure and increases the solubility of the HAp powder [16]. In addition, the HAp particles imaged in this study exhibited the typical small oval shapes (Figure 4(e)) previously reported for HAp substitution with $\mathrm{Si}$, e.g., Tsalsabila et al. [62] and Gibson et al. [63].

Other studies have indicated that controlling the equilibrium between the crystallinity and the biosolubility of the Si-HAp coating improves cell growth [41], a fact that was reflected in the present investigation, in which the fraction of added $\mathrm{Si}$, along with the added fraction of PLGA, allowed for good adhesion of the osteoblastic cells seeded on the material, likely due to the increased porosity of the modified material reported here. A continuous monolayer of osteoblast cells adhered to the surface of the experimental material (HAp/Si/PLGA) was also observed, with the presence of filopodia characteristic of osteoblasts (Figure 4(d) top) and the observation of a large quantity of living cells inside the material, as revealed by FCS (Figure 4(c) top). The control material containing HAp/PLGA without Si exhibited a lower material porosity, the formation of a discontinuous monolayer, and a lower percentage of viable cells (Figures 4(c) and 4(d) middle); this suggests that the pores that the Si creates on the material and its interconnectivity are necessary for the cells to adhere and form an adequate monolayer, allowing it to survive. On the other hand, the $\mathrm{HAp} / \mathrm{Si}$ material used as an additional control showed that in the absence of PLGA, it is a very fragile and rough material (Figures 5(a) and 5(b)) and in contact with the culture medium this material lost its architecture. However, it showed cell viability (Figure 5(c)) and formation of a monolayer, which showed breakage due to the fracture of the material that had been disintegrating (Figure 5(d)).

The biocompatibility results of the HAp samples combined with Si and PLGA (HAp/Si/PLGA) were consistent with those found by Gutierrez-Prieto et al. [19], in which the viability of osteoblast cells extracted from the knee was assessed for 4 materials (bovine bone, HAp, silicon, and collagen) by using SEM and fluorescence microscopy. Three of these materials were also used in the present study. Our results showed a high percentage of viability across the 4 material samples. A similar study was carried out by Parra et al. [64], in which the addition of Si and $\mathrm{Mg}$ to tricalcium phosphate significantly improved the viability and proliferation of the osteoblasts.

However, some studies have shown that in excessive amounts, the incorporated $\mathrm{Si}$ interferes with cell binding to the material because the $\mathrm{Si}$ significantly influences the nanocrystallinity of the Si-substituted HAp. As a result, the modified structure alters the interface between the bone cell and the biomaterial and induces bone cell apoptosis due to the loss of cellular anchoring $[65,66]$.

Thus, the addition of an adequate proportion of $\mathrm{Si}$ significantly improves the properties of the HAp material and gives the material greater bioactivity because it increases its protein adsorption capacity, improves adhesion and cell proliferation, and promotes greater control over the viscosity and stiffness of hydrogels, polymers, and ceramics. However, some in vivo studies have indicated that the combination of HAp and Si can occasionally generate an inflammatory response $[67,68]$.

PLGA was also added to the HAp in this study. This polymer has been shown to modify the biodegradability and 
interconnectivity properties of the HAp material and improve its cellular colonization. Likewise, this material neither seems to affect the ionic concentrations of $\mathrm{Ca}$ and $\mathrm{P}$, nor the surrounding $\mathrm{pH}[59,69]$. The freezing-lyophilization method used to add PLGA in the present study was the same technique proposed by Raman [60], which was fast and efficient. However, it is important to manage the proportion of PLGA added with Si-doped HAp because depending on the concentration of HAp, the function of the seeded osteoblastic cells can either be stimulated or not. Therefore, in this study, it was decided to use a ratio of $1: 3$ by weight (0.73 g PLGA: $2.19 \mathrm{~g} \mathrm{HAp} / \mathrm{Si}$ ), corresponding to a greater amount of $\mathrm{HAp} / \mathrm{Si}$ with respect to PLGA.

On the other hand, the literature reports that bovine HAp combined with PLGA (BB/PLGA) tends to induce greater bioactivity than other forms of $\mathrm{HA}[9,10]$. The results of SEM and FCM in the present study suggest that the results of the BB/PLGA material, one of the materials used as a control (figure not shown) although it presented viability, were not as significant as that presented by the experimental material (HAp/Si/PLGA) and the PLGA control material. This is possibly because although HAp by itself helps cell adhesion for its porosity $[63,68]$, mixing it with $\mathrm{Si}$ and PLGA seems to increase its viability (Figures 4(c), 4(d), and 4(d) top).

In the present study, a HAp/Si/PLGA compound was obtained to be used as a scaffold allowing bone regeneration for its use in dentistry. For this material elaboration, properties reported in the literature for each of the elements were considered. The results obtained show that either macroscopically and microscopically, the material obtained has an irregular, porous, and rough structure, with relatively hexahedral shapes, typical of bone tissue (Figures 4(a) and 4(b) top) that allows the adhesion of osteoblastic cells on its surface (Figure $4(\mathrm{~d})$ top SEM) and a cell viability of $96 \%$ (Figure 4(c) top FCM and Figure 4(e)).

These results also suggest that the proportions used of the 3 compounds (1 PLGA:3 HAp/Si) for their preparation, seem to be adequate since the porous material obtained showed very little disintegration in contact with the medium, practically retaining its initial architecture and showing a high cellular viability that it is apparently influenced by the proportions of the PLGA [45]. As for its biocompatibility, it could be that it is not only because of Si on HAp, but it could also have influenced $\mathrm{Si}$ on the surface of PLGA, making it more hydrophilic and allowing greater cell adhesion [43].

\section{Conclusions}

In this study, a HAp material was prepared from chicken eggshells modified with $\mathrm{Si}$ and PLGA polymer. Subsequently, these HAp samples were evaluated, with the results demonstrating that the resulting material is bioactive and biocompatible and can be used in the future for the construction of three-dimensional scaffolding, serving as a key element for bone regeneration. This material is also considered promising not only because of the characteristics studied here but also because of its self-sustainability, low cost, and future clinical applicability in the fields of dentistry and medicine. However, future studies with stem cells seeded on this material should be conducted to determine whether this material provides an adequate environment for these cells to differentiate. In addition, studies evaluating its biodegradability and mechanical properties are necessary.

\section{Data Availability}

The data used to support the findings of this study are available from the corresponding author upon request.

\section{Conflicts of Interest}

The authors declare no conflicts of interest.

\section{Acknowledgments}

The authors also express their gratitude to the Dental Research Center of the School of Odontology, Department of Chemistry, and Group of Thin Films and Nanophotonics (Department of Physics) of the Faculty of Sciences from PUJ. The authors thank the Vice Rector of Research from Pontificia Universidad Javeriana (PUJ) for financial support (grant nos. 6290 and 8948).

\section{Supplementary Materials}

The graphic abstract is included and is titled "Material HAp/ Si/PLGA elaboration.” (Supplementary Materials)

\section{References}

[1] G. K. Chan and G. Duque, "Age-related bone loss: old bone, new facts," Gerontology, vol. 48, no. 2, pp. 62-71, 2002.

[2] M. A. Reynolds, M. E. Aichelmann-Reidy, and G. L. BranchMays, "Regeneration of periodontal tissue: bone replacement grafts," Dental Clinics of North America, vol. 54, no. 1, pp. 55-71, 2010.

[3] C. Mauffrey, M. Madsen, R. J. Bowles, and D. Seligson, "Bone graft harvest site options in orthopaedic trauma: a prospective in vivo quantification study," Injury, vol. 43, no. 3, pp. 323-326, 2012.

[4] S. V. Dorozhkin, "Nanodimensional and nanocrystalline apatites and other calcium orthophosphates in biomedical engineering, biology and medicine," Materials (Basel), vol. 2, no. 4, pp. 1975-2045, 2009.

[5] C. Laurencin, Y. Khan, and S. F. El-Amin, "Bone graft substitutes," Expert Review of Medical Devices, vol. 3, no. 1, pp. 49-57, 2006.

[6] C. Balázsi, F. Wéber, Z. Kövér, E. Horváth, and C. Németh, "Preparation of calcium-phosphate bioceramics from natural resources," Journal of the European Ceramic Society, vol. 27, no. 2-3, pp. 1601-1606, 2007.

[7] M. Swetha, K. Sahithi, A. Moorthi, N. Srinivasan, K. Ramasamy, and N. Selvamurugan, "Biocomposites containing natural polymers and hydroxyapatite for bone tissue engineering," International Journal of Biological Macromolecules, vol. 47, no. 1, pp. 1-4, 2010.

[8] S. V. Dorozhkin, "Bioceramics of calcium orthophosphates," Biomaterials, vol. 31, no. 7, pp. 1465-1485, 2010.

[9] D. L. Hoexter, "Bone regeneration graft materials," The Journal of Oral Implantology, vol. 28, no. 6, pp. 290-294, 2002. 
[10] L. G. Sequeda, J. M. Díaz, S. J. Gutiérrez, S. J. Perdomo, and O. L. Gómez, "Obtención de hidroxiapatita sintética por tres métodos diferentes y su caracterización para ser utilizada como sustituto óseo," Revista Colombiana de Ciencias Químico - Farmacéuticas, vol. 41, pp. 50-66, 2012.

[11] Y. Wang, S. Zhang, K. Wei, N. Zhao, J. Chen, and X. Wang, "Hydrothermal synthesis of hydroxyapatite nanopowders using cationic surfactant as a template," Materials Letters, vol. 60 , no. 12, pp. 1484-1487, 2006.

[12] T. Yuasa, Y. Miyamoto, K. Ishikawa et al., "Effects of apatite cements on proliferation and differentiation of human osteoblasts in vitro," Biomaterials, vol. 25, no. 7-8, pp. 1159-1166, 2004.

[13] A. Arboleda, M. Franco, J. Caicedo, and C. Goyes, "Congreso internacional de Materiales," in Síntesis de hidroxiapatita nanoestructurada a partir de cáscaras de huevo para aplicaciones médicas, U. A. d. Occidente, Ed., pp. 97-102, Cali, Colombia, 2011.

[14] V. Kattimani, K. P. Lingamaneni, P. S. Chakravarthi, T. S. Kumar, and A. Siddharthan, "Eggshell-derived hydroxyapatite: a new era in bone regeneration," The Journal of Craniofacial Surgery, vol. 27, no. 1, pp. 112-117, 2016.

[15] S. W. Lee, S. G. Kim, C. Balazsi, W. S. Chae, and H. O. Lee, "Comparative study of hydroxyapatite from eggshells and synthetic hydroxyapatite for bone regeneration," Oral Surgery, Oral Medicine, Oral Pathology and Oral Radiology, vol. 113, no. 3, pp. 348-355, 2012.

[16] S.-W. Lee, C. Balázsi, K. Balázsi et al., "Comparative Study of hydroxyapatite prepared from seashells and eggshells as a bone graft material," Tissue Engineering and Regenerative Medicine, vol. 11, no. 2, pp. 113-120, 2014.

[17] J. W. Park, S. R. Bae, J. Y. Suh et al., "Evaluation of bone healing with eggshell-derived bone graft substitutes in rat calvaria: a pilot study," Journal of Biomedical Materials Research. Part A, vol. 87, no. 1, pp. 203-214, 2007.

[18] S. Kanhed, S. Awasthi, S. Goel et al., "Porosity distribution affecting mechanical and biological behaviour of hydroxyapatite bioceramic composites," Ceramics International, vol. 43, no. 13, pp. 10442-10449, 2017.

[19] S. J. Gutierrez-Prieto, S. J. Perdomo-Lara, J. M. Diaz-Peraza, and L. G. Sequeda-Castaneda, "Analysis of in vitro osteoblast culture on scaffolds for future bone regeneration purposes in dentistry," Advances in Pharmacological Sciences, vol. 2019, Article ID 5420752, 9 pages, 2019.

[20] X. Li, S. Zhang, X. Zhang, S. Xie, G. Zhao, and L. Zhang, "Biocompatibility and physicochemical characteristics of Poly( $\varepsilon$-Caprolactone)/poly(lactide-Co-Glycolide)/nano-Hydroxyapatite composite scaffolds for bone tissue engineering," Materials \& Design, vol. 114, pp. 149-160, 2017.

[21] L. Tan, X. Yu, P. Wan, and K. Yang, "Biodegradable materials for bone repairs: a review," Journal of Materials Science \& Technology, vol. 29, no. 6, pp. 503-513, 2013.

[22] R. A. Surmenev, S. Shkarina, D. S. Syromotina et al., "Characterization of biomimetic silicate- and strontiumcontaining hydroxyapatite microparticles embedded in biodegradable electrospun polycaprolactone scaffolds for bone regeneration," European Polymer Journal, vol. 113, pp. 67-77, 2019.

[23] D. Mao, Q. Li, N. Bai, H. Dong, and D. Li, "Porous stable poly(lactic acid)/ethyl cellulose/hydroxyapatite composite scaffolds prepared by a combined method for bone regeneration," Carbohydrate Polymers, vol. 180, pp. 104-111, 2018.

[24] I. Kaya, M. C. Sahin, I. D. Cingoz et al., "Three dimensional printing and biomaterials in the repairment of bone defects; hydroxyapatite PLA filaments," Turkish Journal of Medical Sciences, vol. 49, no. 3, pp. 922-927, 2019.

[25] T. Ahmadi, A. Monshi, V. Mortazavi et al., "Fabrication and characterization of polycaprolactone fumarate/gelatin-based nanocomposite incorporated with silicon and magnesium codoped fluorapatite nanoparticles using electrospinning method," Materials Science and Engineering: C, vol. 106, Article ID 110172, 2020.

[26] L. Casarrubios, M. C. Matesanz, S. Sanchez-Salcedo, D. Arcos, M. Vallet-Regi, and M. T. Portoles, "Nanocrystallinity effects on osteoblast and osteoclast response to silicon substituted hydroxyapatite," Journal of Colloid and Interface Science, vol. 482, pp. 112-120, 2016.

[27] N. K. Nga, T. T. Hoai, and P. H. Viet, "Biomimetic scaffolds based on hydroxyapatite nanorod/poly(D,L) lactic acid with their corresponding apatite-forming capability and biocompatibility for bone-tissue engineering," Colloids and Surfaces. B, Biointerfaces, vol. 128, pp. 506-514, 2015.

[28] P. Gentile, V. Chiono, I. Carmagnola, and P. V. Hatton, "An overview of poly(lactic-co-glycolic) acid (PLGA)-based biomaterials for bone tissue engineering," International Journal of Molecular Sciences, vol. 15, no. 3, pp. 3640-3659, 2014.

[29] N. Patel, S. Best, and W. Bonfield, "Characterisation of hydroxyapatite and substituted-hydroxyapatites for bone grafting," Journal of the Australasian Ceramic Society, vol. 41, pp. 1-22, 2005.

[30] M. Mucalo, Hydroxyapatite (HAp) for Biomedical Applications, Elsevier Science, Amsterdam, Netherlands, 2015.

[31] A. Aminian, M. Solati-Hashjin, A. Samadikuchaksaraei et al., "Synthesis of silicon-substituted hydroxyapatite by a hydrothermal method with two different phosphorous sources," Ceramics International, vol. 37, no. 4, pp. 1219-1229, 2011.

[32] A. Baeza, I. Izquierdo-Barba, and M. Vallet-Regí, "Biotinylation of silicon-doped hydroxyapatite: a new approach to protein fixation for bone tissue regeneration," Acta Biomaterialia, vol. 6, no. 3, pp. 743-749, 2010.

[33] G. Tomoaia, A. Mocanu, I. Vida-Simiti et al., "Silicon effect on the composition and structure of nanocalcium phosphates: in vitro biocompatibility to human osteoblasts," Materials Science and Engineering: C, vol. 37, pp. 37-47, 2014.

[34] A. F. Khan, M. Saleem, A. Afzal, A. Ali, A. Khan, and A. R. Khan, "Bioactive behavior of silicon substituted calcium phosphate based bioceramics for bone regeneration," Materials Science \& Engineering: C, vol. 35, pp. 245-252, 2014.

[35] E. S. Thian, J. Huang, S. M. Best et al., "The response of osteoblasts to nanocrystalline silicon-substituted hydroxyapatite thin films," Biomaterials, vol. 27, no. 13, pp. 2692-2698, 2006.

[36] N. Patel, S. M. Best, W. Bonfield et al., "A comparative study on the in vivo behavior of hydroxyapatite and silicon substituted hydroxyapatite granules," Journal of Materials Science. Materials in Medicine, vol. 13, no. 12, pp. 1199-1206, 2002.

[37] A. M. Pietak, J. W. Reid, M. J. Stott, and M. Sayer, "Silicon substitution in the calcium phosphate bioceramics," Biomaterials, vol. 28, no. 28, pp. 4023-4032, 2007.

[38] M. Bohner, "Silicon-substituted calcium phosphates-a critical view," Biomaterials, vol. 30, no. 32, pp. 6403-6406, 2009.

[39] A. E. Porter, S. M. Best, and W. Bonfield, "Ultrastructural comparison of hydroxyapatite and silicon-substituted hydroxyapatite for biomedical applications," Journal of Biomedical Materials Research. Part A, vol. 68, no. 1, pp. 133-141, 2004.

[40] K. Szurkowska and J. Kolmas, "Hydroxyapatites enriched in silicon - bioceramic materials for biomedical and pharmaceutical 
applications," Progress in Natural Science: Materials International, vol. 27, no. 4, pp. 401-409, 2017.

[41] S. Seet, "Silicon-substituted calcium phosphate compounds: synthesis, characterization, and bioactivity evaluation," ScienceAsia, vol. 35, pp. 255-260, 2009.

[42] Q. Yang, Y. Du, Y. Wang et al., "Si-doping bone composite based on protein template-mediated assembly for enhancing bone regeneration," Frontiers of Materials Science, vol. 11, no. 2, pp. 106-119, 2017.

[43] S. He, K. F. Lin, Z. Sun et al., "Effects of nano-hydroxyapatite/ poly(DL-lactic-co-glycolic acid) microsphere-based composite scaffolds on repair of bone defects: evaluating the role of nano-hydroxyapatite content," Artificial Organs, vol. 40, no. 7, pp. E128-E135, 2016.

[44] Z. Pan and J. Ding, "Poly(lactide-co-glycolide) porous scaffolds for tissue engineering and regenerative medicine," Interface Focus, vol. 2, no. 3, pp. 366-377, 2012.

[45] D. Torres-Lagares, L. Castellanos-Cosano, M. A. SerreraFigallo et al., "In Vitro and in vivo study of poly(lactic(-)co(-) glycolic) (PLGA) membranes treated with oxygen plasma and coated with nanostructured hydroxyapatite ultrathin films for guided bone regeneration processes," Polymers, vol. 9, no. 9, 2017.

[46] C. B. Danoux, D. Barbieri, H. Yuan, J. D. de Bruijn, C. A. van Blitterswijk, and P. Habibovic, "In vitro and in vivo bioactivity assessment of a polylactic acid/hydroxyapatite composite for bone regeneration," Biomatter, vol. 4, Article ID e27664, 2014.

[47] M. Ngiam, S. Liao, A. J. Patil, Z. Cheng, C. K. Chan, and S. Ramakrishna, "The fabrication of nano-hydroxyapatite on PLGA and PLGA/collagen nanofibrous composite scaffolds and their effects in osteoblastic behavior for bone tissue engineering," Bone, vol. 45, no. 1, pp. 4-16, 2009.

[48] S. J. Lee, G. J. Lim, J. W. Lee, A. Atala, and J. J. Yoo, "In vitro evaluation of a poly(lactide-co-glycolide)-collagen composite scaffold for bone regeneration," Biomaterials, vol. 27, no. 18, pp. 3466-3472, 2006.

[49] D.-X. Wang, Y. He, L. Bi et al., "Enhancing the bioactivity of Poly(lactic-co-glycolic acid) scaffold with a nano-hydroxyapatite coating for the treatment of segmental bone defect in a rabbit model," International Journal of Nanomedicine, vol. 8, pp. 1855-1865, 2013.

[50] Z. Yuan, P. Wei, Y. Huang et al., "Injectable PLGA microspheres with tunable magnesium ion release for promoting bone regeneration," Acta Biomaterialia, vol. 85, pp. 294-309, 2019.

[51] J. L. Acevedo-Dávila, J. López-Cuevas, G. Vargas-Gutierrez, J. C. Rendón-Angeles, and J. Mendez-Nonell, "Chemical synthesis of bone-like carbonate hydroxyapatite from hen eggshells and its characterization," Boletin de la Sociedad Española de Cerámica y Vidrio, vol. 46, no. 5, pp. 225-231, 2007.

[52] E. M. Rivera, M. Araiza, W. Brostow et al., "Synthesis of hydroxyapatite from eggshells," Materials Letters, vol. 41, no. 3, pp. 128-134, 1999.

[53] D. Ungureanu, N. Angelescu, R.-M. Ion, S. Elena Valentina, and C. Zizi Rizescu, "Synthesis and characterization of hydroxyapatite nanopowders by chemical precipitation," in Proceedings of the 10th WSEAS International Conference on Electronics, Hardware, Wireless and Optical Communications, and 10th WSEAS International Conference on Signal Processing, robotics and Automation, and 3rd WSEAS International Conference on Nanotechnology, and 2nd WSEAS International Conference on Plasma-Fusion-Nuclear Physics, Wisconsin, WI, USA, 2011.
[54] K. J. Díaz-Olaya, Synthesis of Hydroxyapatite Doped with Silicon by the Conventional Wet Chemical Precipitation Method, Faculty of Sciences and Education, Universidad Distrital Francisco José de Caldas, Bogotá, Colombia, 2017.

[55] B. Chaudhuri, B. Mondal, D. K. Modak, K. Pramanik, and B. K. Chaudhuri, "Preparation and characterization of nanocrystalline hydroxyapatite from egg shell and $\mathrm{K}_{2} \mathrm{HPO}_{4}$ solution," Materials Letters, vol. 97, pp. 148-150, 2013.

[56] I. R. Gibson, S. M. Best, and W. Bonfield, "Chemical characterization of silicon-substituted hydroxyapatite," Journal of Biomedical Materials Research, vol. 44, no. 4, pp. 422-428, 1999.

[57] B. Moreno, Z. Matamoros, J. Rendón, and K. Yanagisawa, Encuentro Participación de la Mujer en la Ciencia, Síntesis de Soluciones Sólidas De hidroxiapatita Dopada Con Silicio Y Su Caracterización, Centro de Investigaciones en Óptica, Leon, México, 2015.

[58] L. N. Castañeda-Preciado, Synthesis of Hydroxyapatite Doped with Silicon by the Sol-Gel Wet Method, p. 104, Faculty of Sciences and Education, Universidad Distrital Francisco José de Caldas, Bogotá, Colombia, 2017.

[59] M. Savaris, G. L. Braga, V. dos Santos et al., "Biocompatibility assessment of poly(lactic acid) films after sterilization with ethylene oxide in histological study in vivo with wistar rats and cellular adhesion of fibroblasts in vitro," International Journal of Polymer Science, vol. 2017, Article ID 7158650, 9 pages, 2017.

[60] H. Raman, An organic Bovine Hydroxyapatite-PLGA Composites for Bone Tissue, Graduate School, University of Kentucky Lexington, Lexington, KY, USA, 2005.

[61] S. Heinemann, C. Heinemann, M. Jager, J. Neunzehn, H. P. Wiesmann, and T. Hanke, "Effect of silica and hydroxyapatite mineralization on the mechanical properties and the biocompatibility of nanocomposite collagen scaffolds," ACS Applied Materials \& Interfaces, vol. 3, no. 11, pp. 4323-4331, 2011.

[62] A. Tsalsabila, Y. W. Sari, and A. Maddu, "Synthesis of silicon substituted hydroxyapatite using microwave irradiation," in Proceedings of the 2018 1st International Conference on Bioinformatics, Biotechnology, and Biomedical Engineering Bioinformatics and Biomedical Engineering, pp. 1-5, Yogyakarta, Indonesia, October 2018.

[63] R. Gibson, S. M. Best, and W. Bonfield, "Effect of silicon substitution on the sintering and microstructure of hydroxyapatite," Journal of the American Ceramic Society, vol. 85, no. 11, pp. 2771-2777, 2002.

[64] J. Parra, I. H. Garcia Paez, A. H. De Aza, C. Baudin, M. Rocio Martin, and P. Pena, "In vitro study of the proliferation and growth of human fetal osteoblasts on $\mathrm{Mg}$ and $\mathrm{Si}$ co-substituted tricalcium phosphate ceramics," Journal of Biomedical Materials Research. Part A, vol. 105, no. 8, pp. 2266-2275, 2017.

[65] I. Barrios de Arenas, M. Vásquez, U. Spadavecchia, S. Camero, and G. González, "Estudio comparativo de la bioactividad de diferentes materiales cerámicos sumergidos en fluido simulado del cuerpo," Revista Latinoamericana de Metalurgia y Materiales, vol. 25, pp. 23-31, 2005.

[66] E. Zhang, C. Zou, and G. Yu, "Surface microstructure and cell biocompatibility of silicon-substituted hydroxyapatite coating on titanium substrate prepared by a biomimetic process," Materials Science and Engineering: C, vol. 29, no. 1, pp. 298-305, 2009.

[67] K. A. Hing, P. A. Revell, N. Smith, and T. Buckland, "Effect of silicon level on rate, quality and progression of bone healing within silicate-substituted porous hydroxyapatite scaffolds," Biomaterials, vol. 27, no. 29, pp. 5014-5026, 2006. 
[68] H. M. d. Silva, M. Mateescu, A. Ponche et al., "Surface transformation of silicon-doped hydroxyapatite immersed in culture medium under dynamic and static conditions," Colloids and Surfaces B: Biointerfaces, vol. 75, no. 1, pp. 349-355, 2010.

[69] G. Gao, A. F. Schilling, T. Yonezawa, J. Wang, G. Dai, and $\mathrm{X}$. Cui, "Bioactive nanoparticles stimulate bone tissue formation in bioprinted three-dimensional scaffold and human mesenchymal stem cells," Biotechnology Journal, vol. 9, no. 10, pp. 1304-1311, 2014. 


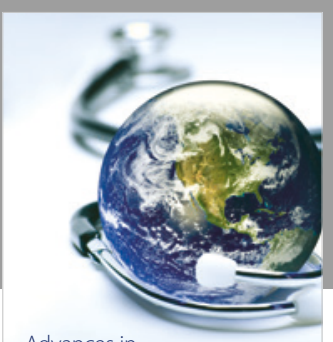

Advances in
Public Health

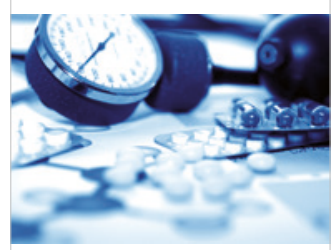

Case Reports in

Medicine

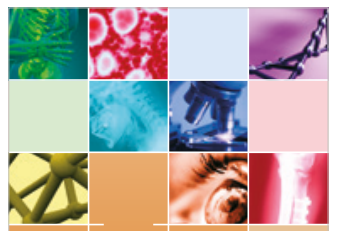

niernational Journal of

Biomaterials
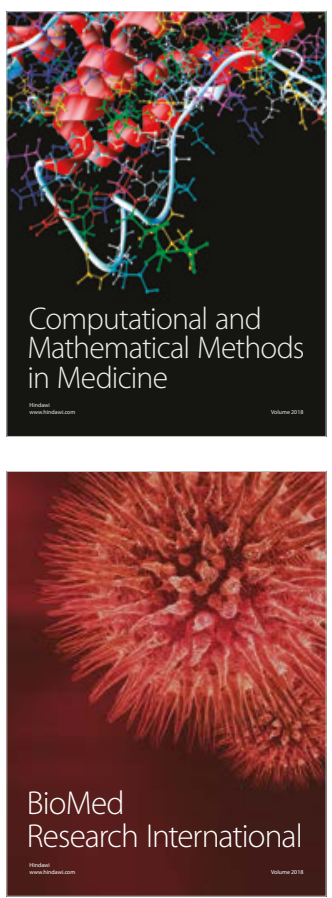

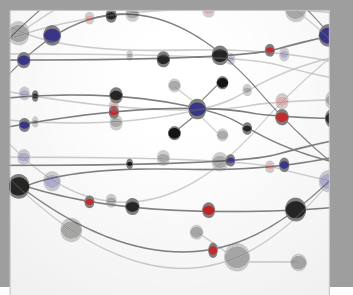

The Scientific World Journal Dentistry

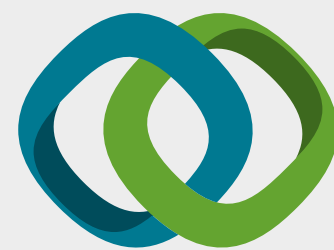

Hindawi

Submit your manuscripts at

www.hindawi.com
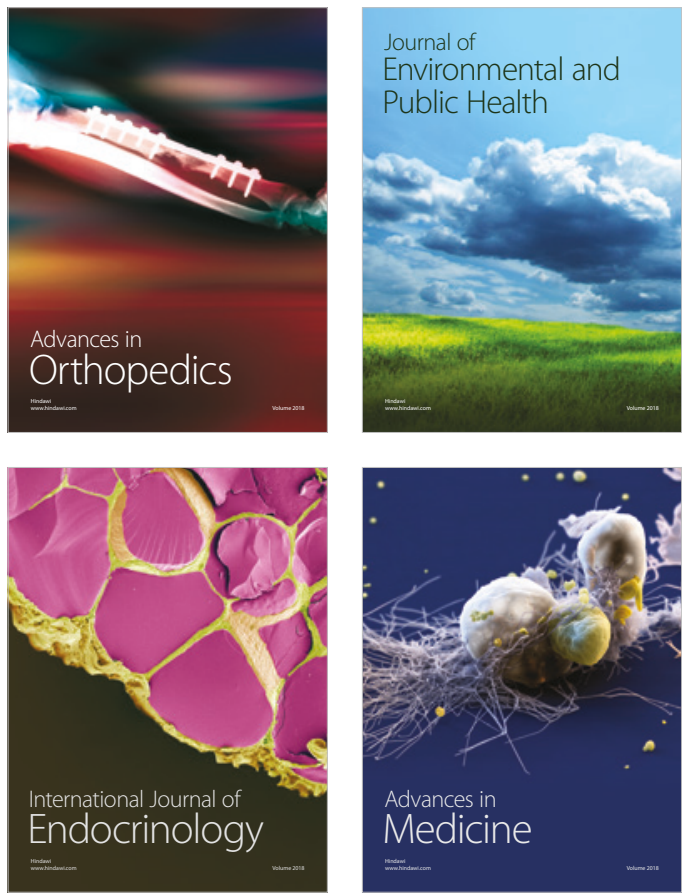
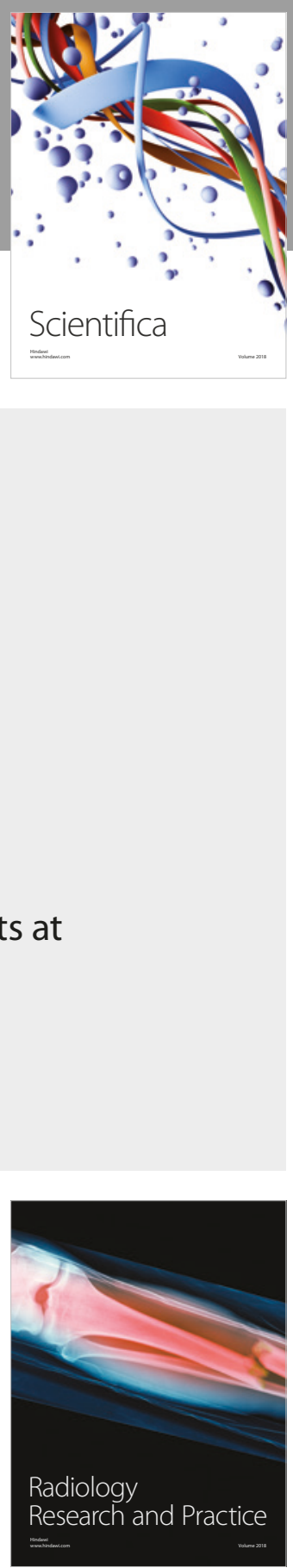

Scientifica

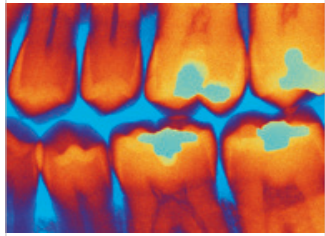

Case Reports in

Dentistry
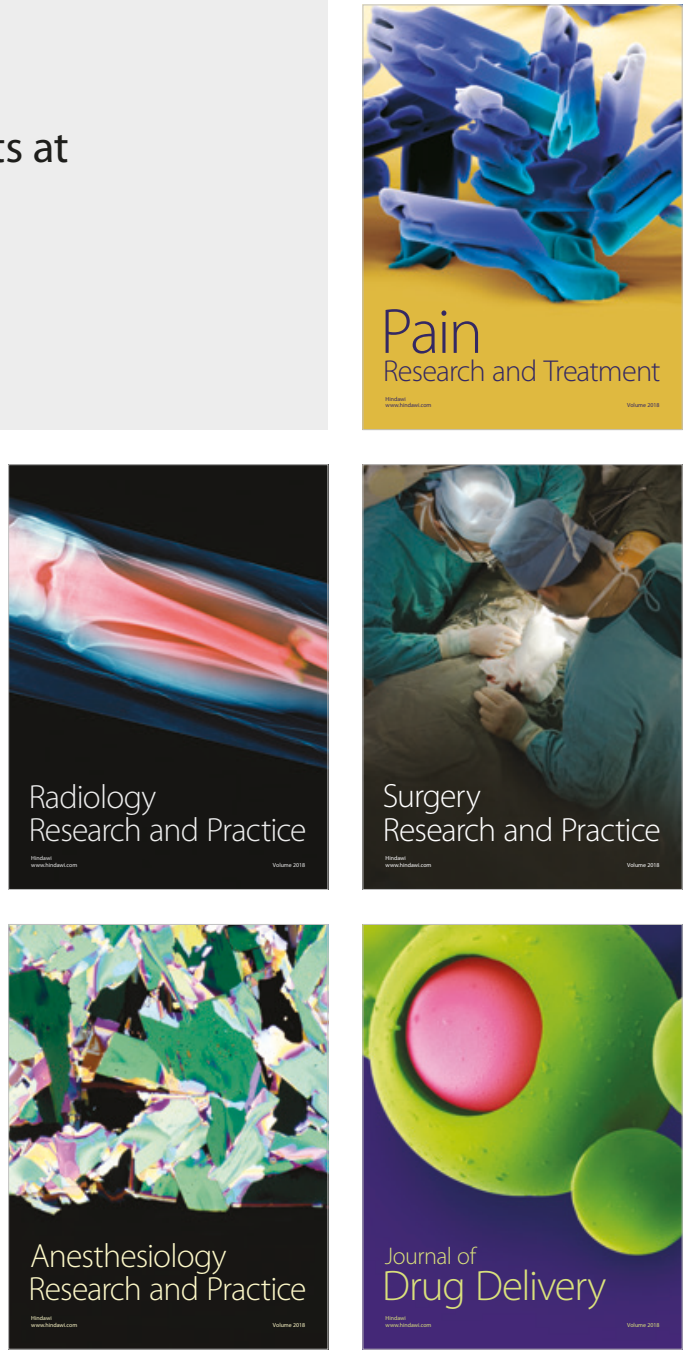